Chairy: Faktor Yang Mempengaruhi Intensi Mengonsumsi Kopi Organik...

\title{
FAKTOR YANG MEMPENGARUHI INTENSI MENGONSUMSI KOPI ORGANIK DI KALANGAN ANAK MUDA
}

\author{
Chairy \\ Fakultas Ekonomi Universitas Tarumanagara Jakarta \\ Email: chairy@pps.untar.ac.id
}

\begin{abstract}
Recently coffee of Indonesia become major attention of world coffee importers as Indonesia has variety of specialty coffee. Drinking coffee is believed as one of trending activities of young people in urban area. This study examined factors affecting intention to consume organic coffee. The sample was 200 undergraduate students of Universitas Tarumanagara who are coffee drinkers. The dependent of this research is intention to consume. Independent variables consist of four variables, they are spirituality, environmental concern, helath concern, and lifestyle. By using regression analysis, this study revealed that spirituality and lifestyle affect intention to consume organic coffee significantly. On the other hand, contrary to previous research, the effect of environmental concern and health concern on intention to consume organic coffee was not significant. This research finding may help marketers of organic coffee in designing their marketing program. They may pay more attention to spirituality and lifestyle aspects in order to suceed in gaining more market share.
\end{abstract}

Keywords: spirituality, environmental concern, health concern, lifestyle, intention to consume.

Abstrak: Akhir-akhir ini kopi Indonesia menjadi perhatian para importir kopi dunia karena variasi dan kekhasannya yang beragam. Di area perkotaan, aktivitas minum kopi sedang marak terutama di kalangan anak muda. Penelitian ini menyelidiki faktor yang mempengaruhi intensi mengonsumsi kopi organik. Sampel penelitian ini adalah 200 orang mahasiswa Universitas Tarumanagara yang merupakan peminum kopi. Variabel terikat dari penelitian ini adalah intensi mengonsumsi kopi. Terdapat empat variabel bebas yaitu spiritualitas, peduli lingkungan, peduli kesehatan, dan gaya hidup. Dengan menggunakan analisis regresi, hasil penelitian menunjukkan bahwa spiritualitas dan gaya hidup mempengaruhi intensi mengonsumsi kopi organik secara positif dan signifikan. Pada sisi yang lain, pengaruh peduli lingkungan dan peduli kesehatan terhadap intensi mengonsumsi kopi organik tidak signifikan. Hasil penelitian ini dapat menjadi masukan bagi para pemasar kopi organik dalam menyusun program pemasaran mereka. Para pemasar kopi ini perlu lebih memberikan perhatian pada aspek spiritualitas dan gaya hidup dalam rangka memperoleh pangsa pasar yang lebih tinggi.

Kata kunci: spiritualitas, peduli lingkungan, peduli kesehatan, gaya hidup, intensi mengonsumsi. 


\section{Chairy: Faktor Yang Mempengaruhi Intensi Mengonsumsi Kopi Organik...}

\section{PENDAHULUAN}

Beberapa tahun terakhir ini fenomena minum kopi sedang tren baik di Indonesia maupun di belahan dunia lainnya. Gerai (outlet) kopi bermunculan baik gerai lokal maupun gerai global berbasis waralaba. Terlepas dari kontroversi apakah tren minum kopi merupakan gaya hidup atau hanya sekedar latah saja, jumlah anak muda peminum kopi semakin bertambah. Mereka minum kopi bukan hanya sekedar melawan rasa kantuk untuk kebutuhan belajar, namun juga untuk kumpul bareng dan melepas penat (https://www.merdeka.com/peristiwa/tren-minum-kopi-diindonesia-gaya-hidup-atau-latah-.html Sabtu 23 Januari 2016, diakses tanggal 23 November 2016).

Pada sisi pasokan, Indonesia dikenal sebagai salah satu negara penghasil kopi terbaik. Selain mutu kopi yang secara umum dilihat dari segi aroma dan cita rasa yang telah dikenal luas sampai mancanegara, Indonesia juga mampu menghasilkan berbagai varian kopi dari berbagai daerah di Indonesia yang masing-masing memiliki cita rasa khas tersendiri. Tekstur tanah dan ketinggian yang beragam menghasilkan kopi yang berbeda antar daerah di Indonesia. Keberagaman lain misalnya kopi luwak yang khas. Kopi ini memberikan tambahan pilihan pada peminum kopi selain kopi import merk terkenal. Indonesia kemudian dinobatkan sebagai surga kopi dunia dalam pameran Specialty Coffee Association of America (SCAA) di Seattle, Amerika Serikat karena Indonesia dinilai memiliki banyak jenis kopi yang tersebar di seluruh daerah di tanah air (https://www.merdeka.com/peristiwa/indonesia-diakui-dunia-sebagai-surga-kopi.html, Sabtu 23 Januari 2016, diakses 23 November 2016).

Selain fenomena minum kopi yang semakin marak, fenomena mengonsumsi produk organik juga menjadi perhatian banyak pemasar. Menurut USDA (United States Department of Agriculture), istilah organik merujuk pada makanan atau produk agrikultural lainnya yang diproduksi dengan menggunakan metode tertentu yang diijinkan seperti memperhatikan masalah perlindungan sumber daya alam, biodiversitas, dan hanya menggunakan bahan-bahan yang diijinkan (https://www.ams.usda.gov/grades-standards/organic-standards, diakses 25 November 2016). Menurut Direktorat Jenderal Tanaman Pangan Kementerian Pertanian Indonesia (2016), pangan organik adalah pangan yang berasal dari suatu lahan pertanian organik yang menerapkan praktek pengelolaan yang bertujuan untuk memelihara ekosistem dalam mencapai produktivitas yang berkelanjutan, dan melakukan pengendalian gulma, hama dan penyakit, melalui berbagai cara seperti daur ulang sisa-sisa tumbuhan dan ternak, seleksi dan pergiliran tanaman, pengelolaan air, pengolahan lahan dan penanaman serta penggunaan bahan hayati.

Dalam skala global, laporan dalam "Global Organic Food Market Forecast \& Opportunities 2020" menunjukan bahwa pasar produk organik global akan tumbuh lebih dari 16\% dalam beberapa tahun ke depan (https://www.techsciresearch.com/report/global-organicfood-market-forecast-and-opportunities-2020/450.html, diakses 25 November 2016). Tumbuhnya pasar produk organik diperkirakan karena meningkatnya pendapatan, perubahan gaya hidup, dan meningkatnya kepedulian konsumen terhadap kesehatan.

Di Indonesia pasar produk organik juga ikut bertumbuh. Mayrowani (2012) melaporkan bahwa walaupun pertumbuhannya relatif lambat, pasar produk organik di Indonesia terus bertumbuh. Indikasinya dapat dilihat dari semakin meningkatnya lahan pertanian organik di Indonesia. Pemerintah Indonesia berencana untuk terus mengembangkan pertanian organik 


\section{Chairy: Faktor Yang Mempengaruhi Intensi Mengonsumsi Kopi Organik...}

secara signifikan. Jahroh (2010) melaporkan bahwa Pemerintah merencanakan mengembangkan hingga 8.500.000 hektar pertanian organik.

Walaupun belum terdapat data yang tepat berkenaan dengan produk organik di Indonesia, permintaan terhadap produk organik cenderung terus meningkat. Produk organik terutama teh, kopi, dan rempah-rempah merupakan produk ekspor utama ke negara-negara di Eropa dan Amerika Utara. Adapun konsumsi dalam negeri lebih didominasi oleh produk organik seperti sayur-sayuran dan beras. Secara umum buah-buahan, sayur-sayuran, beras, dan madu merupakan produk organik yang paling banyak dikonsumsi di pasar domestik (Slamet, Nakayasu, dan Hu Bai, 2016).

Kondisi ini menunjukan menariknya pasar produk organik yang kemudian berdampak pada besarnya perhatian peneliti pada produk organik. Beberapa penelitian tentang konsumsi produk organik misalnya dilakukan oleh Krystallis dan Chryssochoidis (2005) yang menyelidiki tentang kesediaan konsumen membayar produk organik. Hasil penelitian mereka menunjukkan bahwa kualitas, keamanan, kepercayaan, dan merk (untuk beberapa kategori produk) mempengaruhi kesediaan konsumen membayar untuk produk organik.

Setelah meneliti tentang intensi konsumen Finlandia membeli produk organik dengan menggunakan theory of planned behavior (TPB) yang kemudian diterbitkan pada British Food Journal edisi Desember 2005, Tarkiainen dan Sundqvist (2009) meneliti tentang keterlibatan konsumen pada produk organik yang terdiri dari kopi, roti, buah, dan terigu. Hasil penelitian mereka memperlihatkan berbagai alasan konsumen tidak membeli produk organik secara rutin walaupun mereka memiliki sikap yang positif terhadap produk organik.

Selanjutnya penelitian yang dilakukan oleh Paul dan Rana (2012) di India menunjukkan bahwa alasan kesehatan, ketersediaan, dan pendidikan mempengaruhi sikap konsumen terhadap pembelian produk organik. Selain itu kepuasan konsumen terhadap produk organik lebih tinggi daripada produk non organik.

Di Indonesia, beberapa penelitian tentang konsumsi produk organik diantaranya dilakukan oleh Slamet et al (2016). Mereka meneliti tentang faktor penentu pembelian sayuran organik di wilayah Jabodetabek. Hasil penelitian mereka memperlihatkan bahwa konsumen dengan jumlah anggota keluarga yang lebih sedikit, memiliki pendapatan yang lebih tinggi, dan toleran terhadap harga memiliki kemungkinan yang lebih besar untuk membeli produk organik.

Penelitian lain dilakukan oleh Effendi, Ginting, Lubis, dan Fachruddin (2015). Mereka menyelidiki pengaruh pengetahuan tentang produk organik, pengetahuan tentang lingkungan, pengetahuan tentang kesehatan, budaya, atribut produk, norma subjektif, dan sikap produk terhadap intensi membeli produk organik. Hasil penelitian mereka memperlihatkan bahwa hanya pengetahuan tentang produk organik, pengetahuan tentang kesehatan, dan norma subjektif yang mempengaruhi intensi membeli produk organik.

Sejalan dengan meningkatnya konsumsi produk organik pada satu sisi dan menjadi trennya minum kopi di kalangan generasi muda Indonesia pada sisi yang lain, maka penelitian tentang konsumsi kopi organik menjadi relevan. Berdasarkan ulasan penelitian sebelumnya di atas, terlihat bahwa sejauh ini masih sangat terbatas penelitian yang secara khusus menyelidiki fenomena konsumsi kopi organik. Studi ini mencoba mengisi kekosongan penelitian tentang konsumsi kopi organik. 


\section{Chairy: Faktor Yang Mempengaruhi Intensi Mengonsumsi Kopi Organik...}

Variabel bebas pada penelitian ini adalah spiritualitas, peduli lingkungan, peduli kesehatan, gaya hidup. Variabel ini diperoleh dari penelitian sebelumnya tentang konsumsi produk hijau dan organik. Sejauh ini belum terlihat adanya penelitian yang mengkombinasikan keempat variabel bebas di atas dalam konteks konsumsi kopi organik. Yang juga menarik adalah penyertaan spiritualitas dalam konsumsi produk organik. Walaupun spiritualitas telah diperlihatkan mempengaruhi intensi membeli produk hijau (Chairy, 2012), namun sejauh ini belum terlihat penelitian yang secara spesifik menghubungkan spiritualitas dengan konsumsi kopi organik.

Seperti yang telah disebutkan di atas, variabel terikat dalam penelitian ini adalah intensi mengonsumsi kopi organik. Intensi berperilaku (behavioral intention) merupakan variabel yang sering digunakan untuk memprediksi kemungkinan terjadinya perilaku tertentu. Dalam penelitian ini, intensi berperilaku yang digunakan adalah intensi mengonsumsi kopi organik. Hasil penelitian ini diharapkan dapat digunakan oleh pemasar produk kopi organik dalam memasarkan produk mereka. Dengan mengetahui faktor yang mempengaruhi intensi mengonsumsi kopi organik, maka pemasar kopi organik akan sangat dimudahkan dalam menyusun program pemasaran kopi organik.

\section{Intensi Mengonsumsi Kopi Organik}

Intensi mengonsumsi kopi organik diartikan sebagai besarnya kemungkinan konsumen mengonsumsi kopi yang memenuhi kriteria organik. Intensi digunakan sebagai variabel penelitian karena intensi merupakan prediktor terkuat untuk perilaku (Ajzen dan Fishbein, 1980). Intensi diartikan sebagai besarnya kemungkinan seseorang untuk melakukan sesuatu. Dalam penelitian perilaku konsumen, intensi menjadi variabel yang sering digunakan untuk menduga perilaku konsumsi yang ditunjukkan konsumen. Perilaku aktual dalam mengonsumsi kopi organik dapat diprediksi melalui besarnya intensi konsumen untuk mengonsumsi kopi organik.

Penelitian tentang konsumsi produk organik umumnya merupakan bagian dari penelitian tentang perilaku konsumsi berwawasan lingkungan karena produk organik dianggap sebagai bagian dari produk ramah lingkungan atau produk hijau. Penelitian tentang konsumsi produk hijau misalnya dilakukan oleh Chan (2001) pada konsumen China. Intensi membeli produk hijau (green purchase intention) merupakan variabel terikat dalam model penelitiannya. Sejalan dengan theory of reason action (Ajzen dan Fishbein, 1980), intensi membeli produk hijau terbukti merupakan prediktor dari perilaku pembelian hijau. Penelitian serupa dilakukan oleh Junaedi (2006) di Indonesia. Hasil penelitiannya selain membuktikan adanya hubungan yang signifikan antar nilai konsumen, faktor kognitif, faktor afektif, intensi/konatif, dan perilaku, juga memperlihatkan bahwa intensi membeli produk hijau merupakan prediktor yang signifikan dari perilaku beli hijau.

Adapun penelitian yang spesifik tentang intensi membeli produk organik diantaranya dilakukan oleh Zhou, Thogersen, dan Ruan (2013), yang memperlihatkan bahwa intensi membeli produk organik di China dipengaruhi oleh sikap terhadap produk organik dan perceived behavioral control. Seperti yang telah dijelaskan di atas, penelitian di Indonesia tentang konsumsi produk organik diantaranya dilakukan oleh Slamet et al (2016) dan Effendi et al (2015). 


\section{Chairy: Faktor Yang Mempengaruhi Intensi Mengonsumsi Kopi Organik...}

Penelitian yang spesifik tentang pembelian atau konsumsi produk kopi diantaranya dilakukan oleh Chen dan Lee (2015) yang meneliti tentang klaim hijau yang dilakukan oleh kopi Starbuck. Hasil penelitian mereka menunjukan bahwa tiga klaim hijau (green trust, green satisfaction, dan green brand equity) mempengaruhi intensi membeli produk hijau. Penelitian serupa tentang pembelian kopi di Indonesia umumnya membahas tentang kopi merk tertentu seperti yang dilakukan oleh Marbun (2014) pada kopi merk lokal serta Adityo, Darmawan, dan Susrusa (2014) pada kopi merk Starbuck. Semua penelitian di atas juga memperlihatkan bahwa intensi merupakan variabel yang sering digunakan dalam memperkirakan perilaku aktual berkonsumsi.

\section{Spiritualitas}

Spiritualitas didefinisikan sebagai keterlibatan manusia untuk mengeksplorasi sesuatu yang melebihi diri manusia (Kale, 2004). Sebagai salah satu aspek dalam nilai pribadi seseorang, spiritualitas terkait dengan etika berpikir. Dengan demikian spiritualitas menentukan bagaimana seorang individu berperilaku termasuk perilaku berkonsumsi.

Banyak penelitian memperlihatkan bahwa spiritualitas seseorang mempengaruhi perilaku orang tersebut. Umumnya penelitian tentang spiritualitas diterapkan pada perilaku organisasi, sehingga terdapat istilah spiritualitas tempat kerja. Spiritualitas diperlihatkan mempengaruhi baik motivasi maupun kinerja seorang karyawan (Beheshtifar dan Zare, 2013; Hassan, Nadeem, dan Akhter, 2016), dan juga seseorang dengan tingkat spiritual tinggi cenderung merupakan seseorang yang etis dalam berperilaku (McGhee dan Grant, 2008)

Dalam konteks perilaku konsumen, penelitian tentang spiritualitas diantaranya dilakukan oleh Ulvoas-Moal (2010) yang mengeksplorasi pengaruh spiritualitas terhadap perilaku konsumen usia lanjut. Diproposisikan bahwa konsumen usia lanjut memperhatikan dampak konsumsi mereka terhadap lingkungan. Dengan demikian diperkirakan spiritualitas akan mempengaruhi konsumsi produk yang ramah lingkungan. Penelitian lain, yaitu oleh Chairy (2012), memperlihatkan bahwa spiritualitas mempengaruhi konsumsi produk hijau. Dengan demikian diperkirakan spiritualitas juga akan mempengaruhi intensi mengonsumsi kopi organik yang termasuk produk hijau. Berdasarkan uraian di atas, dapat disusun hipotesis pertama sebagai berikut:

H1: Spiritualitas mempengaruhi intensi mengonsumsi kopi organik.

\section{Peduli Lingkungan}

Peduli lingkungan merupakan suatu tingkatan dari keterlibatan secara emosional dalam isu-isu lingkungan (Lee, 2008). Kondisi ini mencerminkan sejauh mana individu memperhatikan lingkungan dengan memperhatikan produk apa saja yang dikonsumsinya dan merefleksikan kekhawatiran konsumen tentang ancaman yang terjadi pada lingkungan.

Studi yang dilakukan oleh Chen (2007) di Taiwan memperlihatkan bahwa konsumen yang memiliki perhatian yang tinggi terhadap lingkungan cenderung memiliki intensi yang lebih tinggi dalam mengonsumsi produk organik. Studi lain dilakukan oleh Tregear, Dent, dan McGregor (1994) memperlihatkan bahwa faktor lingkungan mempengaruhi pembelian produk 


\section{Chairy: Faktor Yang Mempengaruhi Intensi Mengonsumsi Kopi Organik...}

organik. Demikian juga Tan dan Laily (2015) di Malaysia memperlihatkan bahwa faktor lingkungan merupakan pertimbangan dalam mengonsumsi produk organik.

Paul dan Rana (2012) menggunakan istilah ecological awareness untuk menggambarkan konsumen yang peduli terhadap lingkungan. Konsumen pada segmen ini adalah konsumen yang memiliki gaya hidup ekologis seperti sadar akan lingkungan dan memilih produk yang dapat melindungi kelestarian lingkungan. Mereka tertarik pada produk yang ekologis dengan harapan dapat melindungi lingkungan untuk generasi yang akan datang.

Studi terkini yang terkait dengan produk ramah lingkungan dilakukan oleh Kirmani dan Khan (2016) di India. Mereka memperlihatkan bahwa religiositas, kolektivitas, eco-literacy, dan peduli lingkungan merupakan variabel yang berkontribusi pada pembentukan sikap yang positif terhadap produk ramah lingkungan. Pada banyak penelitian diperlihatkan bahwa sikap positif ini yang mendorong pembelian produk ramah lingkungan.

Di Indonesia, penelitian yang dilakukan oleh Slamet et al (2016) selain menjelaskan pengaruh faktor demografis terhadap intensi mengonsumsi produk organik juga membuktikan bahwa sikap, keamanan dan kesehatan, peduli lingkungan dan kepercayanan terhadap atribut organik merupakan determinan pembelian produk organik sayur-sayuran. Untuk peduli lingkungan, Slamet et al (2016) mengoperasionalisasikannya sebagai emisi karbon yang rendah, penggunaan sumber daya yang efisien dan seimbang, kemasan yang ramah lingkungan, dan penumbuhan yang ramah lingkungan.

Mempertimbangkan bahwa kopi organik merupakan salah satu produk organik maka diperkirakan peduli lingkungan akan mempengaruhi intensi mengonsumsi kopi organik. Dengan demikian dapat disusun hipotesis kedua sebagai berikut:

H2: Peduli lingkungan mempengaruhi intensi mengonsumsi kopi organik.

\section{Peduli Kesehatan}

Peduli kesehatan terkait dengan sejauh mana pertimbangan kesehatan dintegrasikan ke dalam aktivitas sehari hari seorang individu (Jayanti dan Burns, 1998). Kesadaran akan kesehatan akan memotivasi seseorang untuk meningkatkan kesehatan masing-masing dengan berbagai cara masing-masing. Dalam konteks penelitian ini peduli kesehatan dikaitkan dengan alasan untuk membeli atau mengonsumsi produk organik.

Lockiea, Lyonsb, Lawrencec, dan Gricec (2004), dalam studi mereka tentang faktor yang mempengaruhi pemilihan produk organik pada konsumen di Australia, memperlihatkan bahwa alasan kesehatan menjadi salah satu faktor yang menentukan pemilihan.

Demikian juga penelitian yang dilakukan di negara lain, misalnya di Hongkong, Yi (2009) meneliti tentang konsumsi produk organik. Variabel yang diperkirakan mempengaruhi konsumsi produk organik adalah faktor demografis, sikap, lingkungan, pengetahuan, dan kesehatan. Hasil penelitiannya memperlihatkan semua variabel di atas memiliki hubungan yang positif dengan frekuensi konsumsi produk organik.

Studi yang dilakukan oleh Paul dan Rana (2012) di India memperlihatkan bahwa pilihan konsumsi seorang konsumen dipengaruhi oleh banyak faktor dengan peduli kesehatan menjadi faktor yang lebih diperhatikan dibandingkan faktor lingkungan atau faktor diet. Faktor kesehatan dipandang lebih mendorong kesediaan konsumen untuk membayar lebih mahal untuk produk 


\section{Chairy: Faktor Yang Mempengaruhi Intensi Mengonsumsi Kopi Organik...}

organik. Uji hipotesis mereka tentang pengaruh manfaat kesehatan terhadap intensi membeli produk organik terbukti signifikan. Studi terkini yang berkaitan dengan produk organik dilakukan oleh Mhlophe (2016) di Afrika Selatan. Hasil penelitiannya menunjukkan bahwa alasan kesehatan merupakan faktor yang menentukan dalam pembelian produk organik.

Berbagai penelitian di Indonesia yang memperlihatkan bahwa pertimbangan kesehatan merupakan faktor yang mempengaruhi pembelian produk organik diantaranya dilakukan oleh Slamet et al (2016) dan Effendi et al (2015). Item yang digunakan untuk mengukur faktor peduli kesehatan memuat kata kunci seperti residu kimiawi, mikro-organisme beracun, pestisida dan pupuk organik, serta kesehatan. Di samping itu, terdapat laporan tentang tumbuhnya pasar kopi organik di Indonesia yang diakibatkan oleh faktor peduli kesehatan dalam berkonsumsi. Berdasarkan uraian di atas, dapat disusun hipotesis ketiga sebagai berikut:

H3: Peduli kesehatan mempengaruhi intensi mengonsumsi kopi organik.

\section{Gaya Hidup}

Menurut Hawkins dan Mothersbaugh (2014), pada dasarnya gaya hidup berkaitan dengan bagaimana seseorang hidup yaitu aktifitas, minat, kesukaan, sikap, konsumsi, ekspektasi dan perasaan-nya. Gaya hidup seseorang mempengaruhi semua aspek perilaku konsumsinya. Dalam konteks perilaku konsumen, Solomon (2015) mengartikan gaya hidup sebagai pola konsumsi yang merefleksikan pilihan seseorang mengenai bagaimana ia melewatkan waktu dan membelanjakan uang yang dimilikinya.

Dalam penelitian ini diduga gaya hidup mempengaruhi intensi mengonsumsi kopi organik. Beberapa penelitian sebelumnya yang dapat dijadikan rujukan pendugaan di atas misalnya penelitian oleh Bashaa, Masonb, Shamsudinc, Hussainc, dan Salemc (2015). Dalam penelitian mereka tentang sikap dan intensi mengonsumsi produk organik, mereka menyertakan variabel gaya hidup. Hasil penelitian mereka menunjukan bahwa gaya hidup merupakan salah satu motif yang muncul dalam mengonsumsi produk organik. Penelitian serupa dilakukan oleh Kouya, Sangkumchaliangb, dan Adittoc (2016) di Kamboja dengan hasil yang sama. Gaya hidup yang ramah lingkungan secara signifikan mempengaruhi intensi membeli produk organik.

Penelitian lainnya dilakukan oleh Florenthal dan Arling (2011). Mereka menyelidiki apakah terdapat kaitan gaya hidup hijau dengan produk hijau yang dikonsumsi. Hasil penelitian mereka menunjukan bahwa konsumen dengan gaya hidup hijau menghargai atribut hijau dari produk keterlibatan rendah (low involvement product). Selain itu, laporan dalam "Global Organic Food Market Forecast \& Opportunities 2020" yang telah di ulas di atas menunjukan bahwa pertumbuhan pasar produk organik global diantaranya karena faktor gaya hidup. Demikian juga laporan media di Indonesia yang memperkirakan meningkatnya konsumsi kopi organik karena faktor gaya hidup. Dengan demikian, dapat disusun hipotesis keempat sebagai berikut:

H4: Gaya hidup mempengaruhi intensi mengonsumsi kopi organik.

\section{METODE PENELITIAN}

Penelitian ini menyelidiki faktor yang mempengaruhi intensi mengonsumsi kopi organik pada kalangan muda. Pengumpulan data dilakukan dengan survai yaitu dengan menyebarkan kuesioner kepada responden penelitian. Pengukuran intensi mengonsumsi kopi organik 


\section{Chairy: Faktor Yang Mempengaruhi Intensi Mengonsumsi Kopi Organik...}

diadaptasi dari skala yang digunakan oleh Chen dan Lee (2015) untuk mengukur intensi membeli kopi Starbuck. Mereka mengukur intensi berperilaku ini dengan tiga item sebagai berikut: "After seeing the above information, I would consider going to Starbucks"; "After seeing the above information, the probability that I would consider choosing Starbucks is high"; dan "After seeing the above information, I would recommend Starbucks to others. Item ini kemudian diterjemahkan dan disesuaikan dengan kondisi penelitian sehingga berbunyi sebagai "saya mempertimbangkan untuk mengonsumsi kopi organik', “kemungkinan memilih mengonsumsi kopi organik tinggi”, "saya akan merekomendasikan kepada orang lain untuk mengonsumsi kopi organik." Studi pendahuluan dengan menggunakan item di atas menghasilkan cronbach alpha sebesar 0,82 sehingga memenuhi syarat untuk digunakan dalam mengumpulkan data selanjutnya.

Pengukuran spiritualitas menggunakan empat item seperti yang digunakan oleh Chairy (2012). Item tersebut merupakan hasil adaptasi dari Stillman, Fincham, Vohs, Lambert, dan Phillips (2012) yang berbunyi: "I feel God's presence", "I experience a connection to all life", "I feel a selfless for others", dan "I feel deep inner peace and harmony". Keempat item ini kemudian diterjemahkan dan disesuaikan dengan kondisi penelitian sehingga berbunyi sebagai "Saya merasakan kehadiran Tuhan", "Saya mengalami keterkaitan dengan semua kehidupan", "Saya merasa tidak sendirian", dan "Saya merasa damai dan adanya harmoni kehidupan." Adapun cronbach alpha yang diperoleh dari studi pendahulun untuk variabel ini adalah sebesar 0,87 sehingga memenuhi syarat untuk digunakan dalam pengumpulan data.

Pengukuran peduli lingkungan menggunakan empat item yang digunakan oleh Slamet et al (2016) yang terdiri dari "low carbon emissions", "balance and efficient in resources uses", "environmentally friendly packaging", dan "environmentally friendly cultivation" yang diterjemahkan sebagai "emisi karbon yang rendah", "penggunaan sumber daya yang efisien dan seimbang", "kemasan yang ramah lingkungan", dan "penumbuhan yang ramah lingkungan". Studi pendahuluan menghasilkan cronbach alpha sebesar 0,81 untuk variabel ini.

Pengukuran peduli kesehatan menggunakan item yang diadaptasi dari Slamet et al (2016) yang berbunyi "I prefer to buy vegetables that have met chemical residue's standard", "It is important to purchase vegetables that are free from pathogenic microorganisms", "I prefer to buy vegetables cultivated using organic pesticides, herbicides and fertilizers", dan "I consume vegetables to keeps me and my family healthy." Keempat item ini kemudian diterjemahkan dan disesuaikan untuk produk kopi sehingga berbunyi sebagai "Saya lebih memilih untuk mengonsumsi kopi yang memiliki residu kimia terbatas", "Penting bagi saya untuk mengonsumsi kopi yang bebas dari mikro-organisme yang berbahaya bagi kesehatan", "Saya lebih memilih kopi yang penanamannya menggunakan pupuk dan pestisida organik", "Saya mengonsumsi kopi untuk menjaga vitalitas tubuh". Cronbach alpha yang diperoleh pada studi pendahuluan adalah sebesar 0,91 .

Pengukuran gaya hidup mengadaptasi item yang digunakan oleh Florenthal dan Arling (2011). Item yang mereka gunakan merupakan item untuk mengukur gaya hidup hijau atau gaya hidup ramah lingkungan. Terdapat tujuh item untuk mengukur gaya hidup hijau sebagai berikut: "I guess I've never actually bought a product because it had lower polluting effect (reversed coded)", "I make a special effort to buy products in recyclable containers", "I have switched products for ecological reasons", "I have attended a meeting of an organization specifically 


\section{Chairy: Faktor Yang Mempengaruhi Intensi Mengonsumsi Kopi Organik...}

concerned with bettering the environment", "I subscribe to ecological publications, "I recycle at home or work", dan "I keep track of my congressman and senator's voting records on environment issues". Dengan perlakuan yang sama terhadap variabel sebelumnya, item ini kemudian diterjemahkan dan disesuaikan dengan kondisi penelitian sehingga dihasilkan item dalam bahasa Indonesia sebagai berikut: "Saya membeli produk yang tidak mencemari lingkungan", "Saya berusaha membeli produk yang menggunakan kemasan yang dapat di daur ulang", "Saya beralih membeli produk dengan alasan ekologis", "Saya menghadiri pertemuan tentang usaha membuat lingkungan menjadi lebih baik", "Saya berlangganan publikasi ekologis", "Saya melakukan kegiatan daur ulang di lingkungan saya", dan "Saya mengikuti rekam jejak pimpinan negara tentang isu lingkungan". Studi pendahuluan menghasilkan croncabch alpha sebesar 0.72 dengan mereduksi item di atas menjadi empat item.

Populasi penelitian adalah mahasiswa Universitas Tarumanagara yang merupakan kalangan berusia muda. Pengambilan sampel dilakukan dengan menggunakan pendekatan nonprobabilita yaitu dengan metode convenient. Responden penelitian ini adalah mahasiswa yang bersedia dan dapat dijangkau untuk menjadi sampel dari penelitian ini. Mempertimbangkan pendapat Sekaran dan Bougie (2016) yang mengatakan jumlah sampel lebih besar dari 30 dan kurang dari 500 adalah jumlah yang tepat bagi kebanyakan penelitian, maka jumlah sampel dalam penelitian ini ditentukan sebanyak 200 responden. Responden ini adalah mereka yang sedang mengambil mata kuliah umum (MKU). Selanjutnya data diolah dengan menggunakan software SPSS.

Pengolahan data dilakukan dengan menggunakan analisis regresi berganda. Semua asumsi yang harus dipenuhi untuk uji regresi berganda dilakukan sebelum data dianalisis lebih lanjut. Uji asumsi yang dilakukan adalah multikolinieritas, heteroskedatisitas dan normalitas. Uji multikolinieritas dilakukan dengan melihat VIF (variance inflation factor) yang harus lebih kecil daripada 10, dan hasilnya memenuhi. Uji heteroskedastisitas dilakukan dengan menyusun bagan scatter plot yang mengombinasikan regression standardized residual untuk sumbu tegak dan regression standardized predicted value untuk sumbu mendatar dengan variabel terikat intensi mengonsumsi kopi organik. Titik-titik dalam bagan yang tidak beraturan serta titik-titik menyebar di atas dan di bawah angka 0 pada sumbu $\mathrm{Y}$ menunjukan tidak adanya heteroskedastisitas. Adapun uji normalitas juga dilakukan secara grafis dengan melihat normal p$p$ plot of regression standardized residual dengan variabel terikat intensi mengonsumsi kopi organik, yang memperlihatkan residual data menyebar di sekitar garis diagonal dan mengikuti arah garis diagonal yang menunjukan model regresi tersebut memenuhi asumsi normalitas. Dengan demikian seluruh uji asumsi klasik untuk regresi berganda dapat dipenuhi

\section{HASIL DAN PEMBAHASAN}

Output statistik uji regresi berganda di tampilkan pada Tabel 1, Tabel 2 dan Tabel 3 di bawah ini. Tabel 1 menampilkan hasil uji $\mathrm{F}$ dengan nilai $\mathrm{F}$ statistik sebesar 37,895 dan angka signifikansi sebesar 0,000 yang artinya paling sedikit terdapat satu variabel bebas yang terdiri 


\section{Chairy: Faktor Yang Mempengaruhi Intensi Mengonsumsi Kopi Organik...}

dari spiritualitas, peduli lingkungan, peduli kesehatan, dan gaya hidup, mempengaruhi variabel terikatnya yaitu intensi mengonsumsi kopi organik. Hasil ini juga menunjukkan bahwa model penelitian yang disusun dengan keempat variabel bebas di atas dan satu variabel terikatnya adalah model yang dapat dianalisis lebih lanjut.

Table 1. Uji F - Regresi Berganda

\begin{tabular}{llccccc}
\hline & \multicolumn{7}{c}{ ANOVA $^{\mathrm{a}}$} & & $\mathrm{F}$ & Sig. \\
\hline Model & \multicolumn{7}{c}{ Sum of Squares } & $\mathrm{df}$ & Mean Square & 115.329 & 37.895 & $.000^{\mathrm{b}}$ \\
\hline \multirow{2}{*}{ Regression } & 461.316 & 4 & & & \\
\cline { 2 - 7 } & Residual & 593.464 & 195 & 3.043 & & \\
\cline { 2 - 7 } & Total & 1054.780 & 199 & & & \\
\hline
\end{tabular}

a. Dependent Variable: Intensi

b. Predictors: (Constant), Gaya_Hidup, Peduli_Kesehatan, Spiritualitas, Peduli_Lingkungan

Tabel 2 di bawah ini memperlihatkan nilai koefisien determinasi. Nilai Adjusted $R$ Square-nya adalah sebesar 0,426 yang berarti sebesar 42,6 persen variasi dari intensi mengonsumsi kopi organik dapat dijelaskan oleh variabel bebas dalam model penelitian ini, sedangkan sisanya dijelaskan oleh variabel bebas lain yang tidak disertakan dalam model penelitian ini.

Tabel 2. Koefisien Determinasi (R2)

\begin{tabular}{lcccc}
\multicolumn{4}{c}{ Model Summary } \\
\hline Model & $\mathrm{R}$ & $\mathrm{R}$ Square & Adjusted R Square & $\begin{array}{c}\text { Std. Error of the } \\
\text { Estimate }\end{array}$ \\
\hline 1 & $.661^{\mathrm{a}}$ & .437 & .426 & 1.74454 \\
\hline $\begin{array}{l}\text { a. Predictors: (Constant), Gaya_Hidup, Peduli_Kesehatan, Spiritualitas, } \\
\text { Peduli_Lingkungan }\end{array}$ &
\end{tabular}

Tabel 3 di bawah ini berisi data hasil uji t. Berdasarkan nilai t pada Tabel 3 di bawah ini, maka uji hipotesa dapat dilakukan. Hipotesis pertama berbunyi spiritualitas mempengaruhi intensi mengonsumsi kopi organik. Nilai t untuk spiritualitas adalah 4,161 dengan angka signifikansi sebesar 0,000 yang berarti spiritualitas mempengaruhi intensi mengonsumsi kopi organik secara positif dan signifikan. Dengan demikian hipotesis pertama diterima. Hasil ini sejalan dengan prediksi Chairy (2012) yang menyatakan spiritualitas mempengaruhi intensi membeli produk yang ramah lingkungan. Spiritualitas mendekatkan manusia pada alam dan Sang Pencipta sehingga mendorong manusia atau konsumen untuk berkonsumsi secara bertanggung jawab yaitu dengan tetap menjaga kelestarian lingkungan. Kopi organik yang ditanam dengan tidak menggunakan pupuk dan pestisida kimia yang dapat merusak tanah merupakan produk yang ramah lingkungan yang menjadi pilihan para konsumen dengan tingkat spiritualitas tinggi. 


\section{Chairy: Faktor Yang Mempengaruhi Intensi Mengonsumsi Kopi Organik...}

\begin{tabular}{|c|c|c|c|c|c|c|}
\hline \multirow{2}{*}{\multicolumn{2}{|c|}{ Model }} & \multicolumn{2}{|c|}{ Unstandardized Coefficients } & \multirow{2}{*}{$\begin{array}{c}\begin{array}{c}\text { Standardized } \\
\text { Coefficients }\end{array} \\
\text { Beta }\end{array}$} & \multirow[b]{2}{*}{$t$} & \multirow[b]{2}{*}{ Sig. } \\
\hline & & $\mathrm{B}$ & Std. Error & & & \\
\hline \multirow[t]{5}{*}{1} & (Constant) & 1.432 & .646 & & 2.216 & .028 \\
\hline & Spiritualitas & .252 & .061 & .324 & 4.161 & .000 \\
\hline & Peduli_Lingkungan & .081 & .056 & .119 & 1.430 & .154 \\
\hline & Peduli_Kesehatan & .022 & .052 & .034 & .428 & .669 \\
\hline & Gaya_Hidup & .243 & .058 & .297 & 4.214 & .000 \\
\hline
\end{tabular}

a. Dependent Variable: Intensi

Hipotesis kedua berbunyi peduli lingkungan mempengaruhi intensi mengonsumsi kopi organik. Nilai t yang bersesuaian dengan variabel ini adalah 1,430 dengan angka signifikansi sebesar 0,154 yang lebih besar dari 0,05. Nilai ini membuat hipotesis kedua tidak didukung data yang artinya peduli lingkungan tidak mempengaruhi intensi mengonsumsi kopi organik. Hasil ini bertentangan dengan hasil penelitian sebelumnya yang memperlihatkan bahwa konsumsi produk ramah lingkungan terutama didorong oleh faktor kepedulian terhadap lingkungan (Kirmani dan Khan, 2016; Tan dan Laily, 2015; Paul dan Rana, 2012; Slamet et al, 2016; dan Tregear et al, 1994). Dalam penelitian ini, baik mahasiwa yang tingkat kepedulian lingkungannya tinggi maupun rendah tidak berbeda dalam intensi mengonsumsi kopi organik. Dengan kata lain, bagi mereka keinginan mengonsumsi kopi organik bukan didorong oleh faktor peduli lingkungan namun oleh faktor lainnya. Hasil ini terjadi diperkirakan karena sejauh ini kepedulian terhadap lingkungan belum menjadi perhatian utama dalam perilaku konsumsi para mahasiswa perkotaan.

Hipotesis ketiga adalah peduli kesehatan mempengaruhi intensi mengonsumsi kopi organik. Nilai t yang bersesuaian dengan variabel ini adalah 0,428 dengan angka signifikansi sebesar 0,664 yang jauh lebih besar dari 0,05. Nilai ini membuat hipotesis ketiga ditolak yang artinya peduli kesehatan tidak mempengaruhi intensi mengonsumsi kopi organik. Hasil ini juga bertentangan dengan hasil penelitian sebelumnya yang memperlihatkan bahwa konsumsi produk ramah lingkungan dipengaruhi oleh peduli kesehatan (Effendi et al, 2015; Lockiea et al, 2004; Mhlophe, 2016; Paul dan Rana, 2012; Slamet et al, 2016; dan Yi, 2009). Hasil ini memperlihatkan bahwa tinggi rendahnya kepedulian konsumen terhadap kesehatannya tidak mempengaruhi intensi mengonsumsi kopi organik. Peduli kesehatan bukanlah faktor yang mendorong para konsumen muda untuk mengonsumsi kopi organik. Hasil ini terjadi diperkirakan karena sejauh ini kopi dianggap bukan sebagai produk yang sehat oleh berbagai kalangan. Dengan demikian walaupun jenis kopinya adalah kopi organik, konsumsi produk ini lebih didorong oleh faktor lain selain peduli kesehatan. Konsumen yang tingkat kepedulian kesehatannya tinggi sangat mungkin tidak mengonsumsi kopi.

Hipotesis keempat adalah gaya hidup mempengaruhi intensi mengonsumsi kopi organik. Nilai t untuk variabel gaya hidup adalah 4,214 dengan angka signifikansi sebesar 0,000 yang berarti gaya hidup mempengaruhi intensi mengonsumsi kopi organik secara positif dan signifikan. Dengan demikian hipotesis keempat didukung data. Hasil ini sejalan dengan penelitian sebelumnya yang dilakukan oleh Bashaa et al (2015), Kouya et al (2016), serta Florenthal dan Arling (2011). Hasil ini juga sejalan dengan laporan dalam "Global Organic Food 


\section{Chairy: Faktor Yang Mempengaruhi Intensi Mengonsumsi Kopi Organik...}

Market Forecast \& Opportunities 2020" yang mengatakan bahwa pertumbuhan pasar produk organik global diantaranya karena faktor gaya hidup.

Berdasarkan hasil penelitian di atas terlihat bahwa intensi mengonsumsi kopi organik dipengaruhi oleh spiritualitas dan gaya hidup. Hasil penelitian ini memunculkan dua rekomendasi yang dapat dijadikan acuan bagi para pemasar kopi organik dalam mendesain program pemasaran mereka. Yang pertama, ketika mendesain iklan kopi organik, pemasar dapat mengedepankan aspek spiritualitas dengan menggambarkan para konsumen kopi organik adalah mereka yang spiritualitasnya tinggi. Spiritualitas dapat dikomunikasikan misalnya melalui pakaian model iklan yang memberi kesan religious atau kedekatan dengan alam dan Sang Pencipta. Demikian juga dengan gestur atau dialog yang mengedepankan aspek spiritualitas. Yang kedua, berdasarkan variabel kedua yang mempengaruhi intensi mengonsumsi kopi organik yaitu gaya hidup, pemasar dapat menggambarkan aktivitas minum kopi sebagai gaya hidup kalangan muda. Segmen anak muda merupakan pasar yang "long lasting", mereka merupakan trendsetter sekaligus membawa kebiasaan berkonsumsi sampai usia lanjut mereka. Apabila mereka dapat dipengaruhi untuk mengonsumsi kopi organik sejak muda, maka diharapkan kebiasaan ini dapat dilanjutkan hingga tahapan usia selanjutnya. Penggambaran gaya hidup dapat dilakukan dengan menggunakan celebrity endorser yang biasanya digambarkan keren dan bergaya yang menarik perhatian segmen anak muda untuk meniru.

Penelitian ini mengambil data hanya dari satu universitas untuk menggambarkan pola konsumsi kopi organik segmen anak muda. Untuk generalisasi hasil penelitian yang lebih baik perlu dipertimbangkan untuk memperluas populasi dengan mengambil sampel dari beberapa universitas di Indonesia. Penelitian ini hanya memeriksa empat determinan intensi mengonsumsi kopi organik yaitu spiritualitas, peduli lingkungan, peduli kesehatan, dan gaya hidup. Sejauh ini penelitian tentang produk organik yang menyertakan variabel yang menggambarkan kedekatan konsumen dengan alam dan Sang Pencipta relatif terbatas. Untuk penelitian lanjutan disarankan untuk menyertakan varabel selain spiritualitas seperti religiousitas, self transcendence, dan alrtruism.

\section{PENUTUP \\ Simpulan}

Penelitian ini menyelidiki pengaruh spiritualitas, peduli lingkungan, peduli kesehatan, dan gaya hidup terhadap intensi mengonsumsi kopi organik. Sesuai dengan hasil penelitian sebelumnya, dibuktikan bahwa spiritualitas dan gaya hidup mempengaruhi intensi mengonsumsi kopi organik secara positif dan signifikan. Berbeda dengan hasil penelitian serupa sebelumnya, pengaruh peduli lingkungan dan peduli kesehatan tidak didukung data. Hasil penelitian yang tidak sesuai dengan penelitian sebelumnya diduga karena konsumen usia muda saat ini belum memandang peduli lingkungan sebagai faktor yang dipertimbangkan dalam aktivitas konsumsi rutin seperti minum kopi. Demikian juga, peduli kesehatan tidak menjadi pertimbangan dalam konsumsi kopi organik karena pada dasarnya minum kopi dipandang bukan sebagai konsumsi yang sehat bagi semua kalangan konsumen

\section{Saran}




\section{Chairy: Faktor Yang Mempengaruhi Intensi Mengonsumsi Kopi Organik...}

Berdasarkan hasil penelitian ini, pemasar dapat mengembangkan strategi pemasaran dengan memnafaatkan aspek spiritualitas dan gaya hidup. Kedua aspek ini dapat diintegrasikan dalam tema minum kopi organik. Penelitian selanjutnya dapat memperluas populasi penelitian dengan melibatkan mahasiswa dari berbagai perguruan tinggi besar di Indonesia. Demikian juga penelitian ini perlu menyertakan variabel lain selain spiritualitas seperti religiositas, self transcendence, dan altruism.

\section{DAFTAR RUJUKAN}

Adityo, D., Darmawan, D.P., dan Susrusa, K.B. (2014). Pengaruh karakteristik situasional dan komponen kualitas layanan gerai Starbucks terhadap keputusan pembelian ulang, Jurnal Manajemen Agribisnis, 2 (1): 49-60

Ajzen, I., dan Fishbein, M. (1980). Understanding attitudes and predicting behavior, Englewood Cliffs, NJ: Prentice-Hall.

Bashaa, M.B., Masonb, C., Shamsudinc, M.F., Hussainc, H.I., dan Salemc, M.A. (2015). Consumers attitude towards organic food, Procedia Economics and Finance, 31: 444 452

Beheshtifar, M., dan Zare, I.E. (2013). Effect of spirituality in workplace on job performance, Interdisciplinary Journal of Contemporary Research in Business, 5 (2): 248-254

Chairy (2012). Spirituality, Self Transcendence, and Green Purchase Intention in College Students, Procedia - Social and Behavioral Sciences, 57: 243 - 246

Chan, R.Y.K. (2001). Determinants of Chinese consumers' green purchase behavior, Psychology \& Marketing, 18 (4): 389-413.

Chen, M-F. (2007). Consumer attitudes and purchase intentions in relation to organic foods in Taiwan: Moderating effects of food-related personality traits, Food Quality and Preference, 18 (7): 1008-21.

Chen, M-F., dan Lee, C-L. (2015). The impacts of green claims on coffee consumers' purchase intention, British Food Journal, 117 (1): 195-209

Direktorat Jenderal Tanaman Pangan Kementerian Pertanian (2016). Petunjuk Teknis Fasilitasi Sertifikasi Pertanian Organik.

Effendi, I., Ginting, P., Lubis, A.N., dan Fachruddin, K.A. (2015). Analysis of consumer behavior of organic food in North Sumatra Province, Indonesia, Procedia - Social and Behavioral Sciences, 57: 243 - 246 


\section{Chairy: Faktor Yang Mempengaruhi Intensi Mengonsumsi Kopi Organik...}

Florenthal, B., dan Arling, P. (2011). Do green lifestyle consumers appreciate low involvement green products? Scholarship and Professional Work - Business.Paper 222. http://digitalcommons.butler.edu/cobpapers/222

Gaelle Ulvoas-Moal (2010). Exploring the influence of spirituality: a new perspective on senior consumers' behavior, Advances in Consumer Research, 37: 917-919.

Global Organic Food Market Forecast and Opportunities 2020, https://www.techsciresearch.com/report/global-organic-food-market-forecast-andopportunities-2020/450.html, diakses 25 November 2016.

Hassan, M., Nadeem, A.B., dan Akhter, A. (2016). Impact of workplace spirituality on job satisfaction: Mediating effect of trust, Cogent Business \& Management, 3: 1-15

Hawkins, Del I., dan Mothersbaugh, David L. (2014). Consumer behavior: building marketing strategy, $12^{\text {th }}$ edition, New York: McGraw Hill Education.

Indonesia diakui dunia sebagai surga kopi, https://www.merdeka.com/peristiwa/indonesia-diakui-dunia-sebagai-surga-kopi.html, Sabtu 23 januari 2016, diakses 23 November 2016).

Jahroh, S. (2010). Organic farming development in Indonesa: Lessons learned from organic farming in West Java and North Sumatra, ISDA 2010, Montpellier, France, June $28-30$

Jayanti, R. K., dan Burns, A. C. (1998). The antecedents of preventive health care behavior: An empirical study, Journal of the Academy of Marketing Science, 26(1): 9-15.

Junaidi, M.F.S. (2006). Pengembangan model perilaku konsumen berwawasan lingkungan di Indonesia: Studi perbandingan kota metropolitan dan non metropolitan, Jurnal Ekonomi dan Bisnis Indonesia, 21 (4): 399-419.

Kale, S.H. (2004). Spirituality, Religion, and Globalization, Journal of Macromarketing, 24 (2): 92-107.

Kirmani, M.D., dan Khan, M.N. (2016). Environmental concern to attitude towards green products: Evidences from India, Serbian Journal of Management, 11 (2): 159 - 179

Kouya, S., Sangkumchaliangb, P., dan Adittoc, S. (2016). Consumers' attitude and intention to purchase organic goods in Cambodia, International Journal of Business, 21(4): 328-341 


\section{Chairy: Faktor Yang Mempengaruhi Intensi Mengonsumsi Kopi Organik...}

Krystallis, A., dan Chryssohoidis, G. (2005). Consumers' willingness to pay for organic food: Factors that affect it and variation per organic product type, British Food Journal, 107 (5): 320-343.

Lee, K. (2008). Opportunities for green marketing: young consumers, Marketing Intelligence \& Planning, 26(6): 573-586.

Lockiea, S., Lyonsb, K., Lawrencec, G., dan Gricec, J. (2004). Choosing organics: A path analysis of factors underlying the selection of organic food among Australian consumers, Appetite, 43: 135-146

Marbun, I.I. (2014). Analisis factor-faktor yang mempengaruhi perilaku konsumen kopi luwak bermerek di kota Medan, Skripsi, Program Studi Agribisnis, Fakultas Pertanian, Universitas Sumatera Utara, Medan

Mayrowani, H. (2012). Pengembangan pertanian organik di Indonesia (The development of organic agriculture in Indonesia), Forum Penelitian Agro Ekonomi, 30 (2): 91-108

McGhee, P., dan Grant, P. (2008). Spirituality and ethical behaviour in the workplace: Wishful thinking or authentic reality, Electronic Journal of Business Ethics and Organization Studies, 13 (2): 61-69

Mhlophe, B. (2016). Consumer purchase intentions towards organic food: Insight from South Africa, Business \& Social Sciences Journal, 1 (1): 1-32

Organic Standards, https://www.ams.usda.gov/grades-standards/organic-standards, diakses 25 November 2016.

Paul, J., dan Rana, J. (2012). Consumer behavior and purchase intention for organic food, Journal of Consumer Marketing, 29 (6): 412 - 422

Sekaran, U., dan Bougie, R. J. (2016). Research methods for business: A skill building approach, 7th Edition, Chichester, West Susses P0 19 8SQ: John Wiley \& Sons. 2017

Slamet, A.S., Nakayasu, A., dan Hu Bai. (2016). The determinants of organic vegetable purchasing in Jabodetabek Region, Indonesia, Journal of Business and Management, 4 (1): 44-58.

Solomon, Michael R. (2015). Consumer behavior: buying, having, being, $11^{\text {th }}$ edition, Harlow, Essex CM20 2JE: Pearson Eduction Limited.

Stillman, T.F., Fincham, F.D., Vohs, K.D., Lambert, N.M., dan Phillips, C.A. (2012). The material and immaterial in conflict: Spirituality reduces conspicuous consumption, Journal of Economic Psychology, 33: 1-7 


\section{Chairy: Faktor Yang Mempengaruhi Intensi Mengonsumsi Kopi Organik...}

Tan, P.H., dan Laily, P. (2015). Factors affecting intention to consume organic food products: A study among Chinese college students in Malaysia, International Review of Management and Business Research, 4(1): 352-360

Tarkiainen, A., dan Sundqvist, S. (2009). Product involvement in organic food consumption: Does ideology meet practice?, Psychology and Marketing, 26(9):844 863.

Tregear, A, Dent, J dan McGregor, M. (1994). The demand for organically-grown produce, British Food Journal, 96(4): 21-25

Tren minum kopi di Indonesia, gaya hidup atau latah?, https://www.merdeka.com/peristiwa/tren-minum-kopi-di-indonesia-gaya-hidup-ataulatah-.html, Sabtu 23 Januari 2016, diakses tanggal 23 November 2016).

Yi, L.K. (2009). Consumer behaviour towards organic food consumption in Hong Kong: An empirical study, Bachelor of Business Administration (Honours) Thesis, Hong Kong Baptist University Hong Kong.

Zhou, Y., Thøgersen, J., dan Ruan, Y. (2013). The moderating role of human values in planned behavior: The case of Chinese consumers' intention to buy organic food, Journal of Consumer Marketing, 30(4): 335-344. 